\title{
Funkcjonowanie dziecka $w$ rodzinie z problemem alkoholowym
}

\section{Functioning of a child in a family with the drinking problem}

\begin{abstract}
Streszczenie:
Artykuł koncentruje się wokół sytuacji dziecka w rodzinie z problemem alkoholowym. Zostaje przybliżone pojęcie dysfunkcjonalności rodziny, wynikającej z pojawienia się problemu alkoholowego. Uwydatniony zostaje system funkcjonowania rodziny. Zaprezentowana zostaje analiza pełnionych ról $\mathrm{w}$ dysfunkcjonalnej rodzinie $\mathrm{z}$ uwzględnieniem sfer działania członka rodziny. Wobec przyjętych faktów zostaje zaprezentowana pomoc i wsparcie w wyjściu z określonej roli przyjętej przez członka rodziny.

Słowa kluczowe: dysfunkcjonalność, problem alkoholowy, funkcjonowanie rodziny, dziecko, przyjmowane role, pomoc
\end{abstract}

\begin{abstract}
:
The article focuses on the situation of a child in a family with the drinking problem and describes the concept of family dysfunctionality resulting from the emergence of such problem. It also highlights the family functioning system. Furthermore, it presents an analysis of the roles performed in a dysfunctional family taking into account the spheres of activity of family members. In the face of the adopted facts, assistance and support in getting out of the specific role assumed by a family member are presented. Keywords: dysfunctionality, drinking problem, functioning of a family, child, assumed roles, assistance
\end{abstract}


Żaneta Nieckarz - Funkcjonowanie dziecka $w$ rodzinie...

\section{Wprowadzenie}

Rodzina stanowi najmniejszą grupę społeczną i „najbardziej powszechne środowisko życia człowieka. Rodzinna opieka jest najbardziej pierwotnym typem działalności ludzkiej w stosunku do potomstwa, zarówno w jej historycznym, jak i jednostkowym aspekcie" ${ }^{1}$. Rodzina towarzyszy każdej jednostce $\mathrm{w}$ różnych formach przez całe życie „wywierając istotny wpływ na zachowanie się jednostki, ich stosunek do innych osób, świata wartości, systemu norm i wzorców postępowania. Założenie rodziny kojarzy się z oczekiwaniem szczęścia, miłości, zaspokojenia potrzeb emocjonalnych" 2 .

Rodzina to pierwsze naturalne środowisko wychowawcze, w którym rozpoczyna się proces wychowania jednostki ${ }^{3}$. Stanowi istotny element całościowego systemu wychowawczego ${ }^{4}$. Dziecko od chwili narodzin uczy się i zdobywa potrzebne umiejętności, by właściwie funkcjonować w społeczeństwie. W środowisku rodzinnym jednostka zostaje wyodrębniona oraz staje się członkiem społeczności, co skutkuje budowaniem najważniejszego fundamentu, jakim staje się dobro wspólne. W sytuacji pojawienia się w tej grupie nieprawidłowości, które trwają dłuższy okres czasu, nie jest możliwe powstanie wartościowego społeczeństwa5 . Jedna z nieprawidłowości jest wynikiem nadużywania alkoholu. Powstaje ona, gdy w rodzinie pojawia się problem alkoholowy.

Historia pojawienia się pierwszych informacji o napojach alkoholowych sięga czasów paleolitu i neolitu, gdyż archeologowie natrafili na ślady alkoholu z tego okresu. Towarzyszy on od niepamiętnych czasów

1 S. Badora, B. Czeredrecka, D. Marzec, Rodzina i formy jej wspomagania, Kraków 2001, s. 24.

2 Ibidem.

${ }^{3}$ A. Piech, Rodzina naturalnym środowiskiem wychowawczym, [w:] D. Wosik-Kawala (red.), Rodzinne i instytucjonalne środowisko opiekuńczo-wychowawcze, Lublin 2011, s. 17.

${ }^{4}$ B. Krzesińska-Żach, Pedagogika rodziny. Przewodnik do ćwiczeń, Białystok 2007, s. 10.

${ }^{5}$ R. Cichoń, Formy pracy socjalnej z rodzinq „trudna”, [w:] H. Marzec (red.), Z rodzina i dla rodziny w dobie globalizacji, t. II, Piotrków Trybunalski 2011, s. 201-202. 
człowiekowi na różnych imprezach i uroczystościach ${ }^{6}$. Natomiast za pierwszy przypadek problemu alkoholowego występującego w rodzinie można uznać konflikt Noego z Chamem w czasie niewoli egipskiej Współcześnie badania pokazują, iż dorosły Polak wypija 8,38 litra czystego spirytusu, a 2 miliony osób nadużywa alkoholu, natomiast według raportu PARPA z 2005 roku 800 tysięcy osób jest uzależnionych ${ }^{8}$. Według badań z 2011 roku w Polsce funkcjonuje około 1,5 miliona dzieci z rodzin, w których występuje problem alkoholowy. Dzieci odczuwają jego skutki, co niewątpliwie wpływa na ich rozwój ${ }^{9}$. Celem artykułu jest przedstawienie skutków nadużywania alkoholu w odniesieniu do osoby uzależnionej i członków jej rodziny na podstawie wybranej literatury.

\section{Interpretacja problemu dysfunkcjonalności rodziny z problemem alkoholowym}

Prawidłowo funkcjonująca rodzina stara się dbać o właściwy rozwój swych członków pod każdym względem. W praktyce jednak zdarzają się czasowe zaburzenia i konflikty, lecz sam fakt ich pojawienia się nie przesądza o dysfunkcji rodziny. Kwestią najistotniejszą w takiej sytuacji jest stwierdzenie problemu i wspólne poszukiwanie właściwego rozwiązania ${ }^{10}$.

Rodzina z trwającymi w dłuższym okresie wieloma nieprawidłowościami występującymi w systemie jej funkcjonowania, jeśli nie zostaną poddane udanej próbie ich rozwiązania, może stać się rodziną dysfunk-

\footnotetext{
6 Cz. Cekiera, Uzależnienia - alkoholizm, narkomania, palenie tytoniu. Profilaktyka, terapia i resocjalizacja, B. Urban, J. M. Stanik (red.), Resocjalizacja: teoria i praktyka pedagogiczna, t. 2, Warszawa 2008, s. 22.

7 E. Roman, Alkoholizm, [w:] E. Różycka (red.), Encyklopedia pedagogiczna XXI wieku, t. I, s. 93.

${ }^{8}$ Cz. Cekiera, Uzależnienia - alkoholizm, narkomania ..., op. cit., s. 23.

${ }^{9}$ I. Grzegorzewska, Dorastanie w rodzinach z problemem alkoholowym, Warszawa 2011, s. 7.

10 A. Kozłowska, Znaczenie relacji rodzinnych dla pozytywnego rozwoju dziecka. Diagnoza i terapia, Warszawa 2000, s. 13-14.
} 
Żaneta Nieckarz - Funkcjonowanie dziecka $w$ rodzinie...

cyjną. Jedną z konsekwencji może być to, że zadania względem społeczeństwa nie są należycie spełniane. Członkowie nie mają zaspokajanych podstawowych potrzeb. W zaburzonym systemie funkcjonowania występują nieprawidłowe relacje, wobec tego zostaje zaburzone spełnianie właściwych funkcji. Chaos życia rodzinnego przekłada się na niewłaściwe kontakty $\mathrm{z}$ otoczeniem ${ }^{11}$.

Problem alkoholowy w rodzinie staje się czynnikiem dysfunkcjonalności rodziny utrudniającym prawidłowy rozwój osobowości dziecka, może być również przeszkodą w osiągnięciu sukcesów edukacyjnych, ponieważ pojawiają się różne trudności i zakłócenia12. Obowiązki względem dzieci nie są właściwie wypełniane. Występują problemy, które wynikają z utrudnionego przystosowania się do nowej sytuacji. Potomstwo osoby uzależnionej szuka sposobu funkcjonowania w tych warunkach, w związku z tym przyjmuje role, które negatywnie wpływają na dalsze życie ${ }^{13}$.

Definicja rodziny z problemem alkoholowym ukazuje zaistnienie sytuacji, podczas których jej członek nadmiernie spożywa alkohol i nie jest w stanie tego kontrolować. System funkcjonowania zostaje zaburzony. Spożywanie alkoholu przez jednego z rodziców zaczyna stanowić główną część tego systemu. Wywiera również wpływ na prezentowanie określonego nastawienia, jak również zachowania oraz wszystkich procesów mających miejsce w tej rodzinie. Osoba, która spożywa alkohol, dostarcza pozostałym wielu problemów życiowych, w związku z tym problem alkoholowy dotyczy nie tylko osoby spożywającej alkohol, ale wszystkich jej członków ${ }^{14}$. Rodzina zaczyna być niefunkcjonalna, nieodpowiadająca potrzebom, co oznacza, że stała się niezdolna do właściwego spełniania swych funkcji15.

11 M. Ryś, Rodzina z problemem alkoholowym. Metody badań relacji interpersonalnych $w$ dysfunkcyjnych systemach rodzinnych, Warszawa 2014, s. 9.

${ }^{12}$ A. Lendzion, Patologie środowiska życia dziecka, [w:] J. Daszykowska, A. Łuczyńska (red.), Dziecko w przestrzeni życia społecznego, Stalowa Wola 2013, s. 136.

${ }_{13}$ M. Ryś, Rodzina z problemem alkoholowym..., op. cit., s. 10.

14 Ibidem.

15 K. Gąsior, Funkcjonowanie noo-psychologiczne i problemy psychiczne dorosłych dzieci alkoholików, Warszawa 2012, s. 64. 
Problem alkoholowy występuje w wyniku utraty kontroli spożywania napojów alkoholowych i prowadzi do upajania alkoholowego, a nawet uzależnienia ${ }^{16}$. Nieprawidłowości w funkcjonowaniu osoby spożywającej alkohol pogłębiają się wraz z rozwojem problemu alkoholowego ${ }^{17}$. Odczuwane są zmiany, które wynikają z rozwijania się uzależnienia. Czego konsekwencją jest narastanie negatywnych sytuacji życia codziennego, a prawidłowe relacje członków rodziny są rzadkością. Rodzina zamyka się we własnym środowisku i wypiera istnienie sytuacji problemowej. Potrzeby emocjonalne jej członków nie są zaspokajane. Pojawia się brak organizacji, a pełnione role są zaburzone. Postrzeganie rzeczywistości jest odmienne. Występują negatywne emocje, które powodują, że rodzina nie chce ujawniać swojej sytuacji i wypiera problem. Nie stara się go wyjaśnić, co prowadzi do fałszowania rzeczywistości, braku szczerości. Uczucie wstydu i lęku powoduje, że występują notoryczne kłamstwa ${ }^{18}$. Dziecko, które wychowuje się $\mathrm{w}$ rodzinie z problemem alkoholowym, przeżywa wiele stresujących sytuacji i doświadcza różnych traum. Sytuacje te stanowią codzienność, czego konsekwencją może być zakłócony proces rozwojowy dziecka ${ }^{19}$.

Osoby o niższym statusie społecznym, z problemem alkoholowym w rodzinie, funkcjonują według określonego modelu. Członkowie, jak i sam alkoholik, początkowo wypierają istnienie problemu. Rodzina broni się przed pomocą. Ze względu na występujące często sytuacje stresujące wzrasta napięcie. Usprawiedliwianie alkoholika i racjonalizowanie połączone z zaprzeczeniem istnienia problemu ma zdecydowanie bardziej negatywny wpływ na funkcjonowanie rodziny niż samo spożywanie alkoholu przez osobę uzależnioną. Występuje nieustanne zaprzeczanie wszystkiemu i nie zdawanie sobie sprawy z powagi sytuacji. W związku z tym rodzina zaczyna izolować się od otoczenia, aby

16 I. Pospiszyl, Patologie społeczne, Warszawa 2009, s. 126.

17 I. Grzegorzewska, Dorastanie w rodzinach..., op. cit., s. 77.

18 P. Szczukiewicz, Sposoby adaptacji dzieci w rodzinie alkoholowej, „Świat Problemów" 2016, nr 10, s. 33.

${ }^{19}$ K. Gąsior, Jak uwolnić się od destrukcyjnych przekazów rodzinnych?, „Świat Problemów" 2011, nr 5, s. 21-22. 
Żaneta Nieckarz - Funkcjonowanie dziecka $w$ rodzinie...

ujawniać jak najmniej faktów ze swojego życia. Nieprawidłowe zachowania pogłębiają się. Członkowie nie potrafią się właściwie komunikować, dlatego też stan całkowitego bezładu w relacjach jest na porządku dziennym. Z upływem czasu występuje poczucie bezradności wobec działań, jakie podejmuje osoba uzależniona. Załamuje się system obronny, czego wynikiem staje się doświadczanie silnych emocji ${ }^{20}$.

Wówczas osoba z problemem alkoholowym również zaczyna zauważać swoje postepowanie, pojawiają się wyrzuty sumienia. Rodzina na tym etapie jest już na tyle bezradna, że dopuszcza możliwość przyjęcia pomocy, niekiedy zauważa, że jest ona konieczna. Kolejnym etapem jest izolacja alkoholika od uczestniczenia w życiu rodziny. Zostaje przejęta kontrola nad funkcją, jaką pełni, aby sytuacja została ustabilizowana. Dostrzegana jest zmiana, zauważone wsparcie i pomoc. Osoba uzależniona traci w oczach członków rodziny, gdyż stosuje kary, dręczy psychicznie i fizycznie swych bliskich. Współmałżonek przejmuje funkcje uzależnionego, odbywa wówczas terapię indywidualną jako współuzależniony i pomaga rodzinie. Motywuje osobę uzależnioną do podjęcia leczenia.

Decyzja o podjęciu leczenia wpływa na ustabilizowanie życia rodzinnego. Nierozpoczęcie leczenia powoduje wyizolowanie alkoholika od funkcjonowania czy też wywierania wpływu na sytuację rodzinną. W radykalnym przypadku może zostać separowany fizycznie, czego wynikiem staje się uwolnienie od uciążliwej i niepożądanej jego obecności w domu. W związku z tym pojawić może się wiele skutków tego działania, ponieważ rodzina przeżywa silny stres w wyniku rozpadu systemu rodzinnego. Drastyczna sytuacja może również pozytywnie wpłynąć na sytuację rodzinną. Rezultatem tego jest wzrost motywacji osoby uzależnionej do podjęcia leczenia odwykowego, ponieważ nie chce utracić więzi. Występuje mobilizująca panika. Stanowi to przełom, gdyż to właśnie od osoby uzależnionej zależy to, co będzie się działo w życiu rodziny. Może nastąpić jej rozpad lub będzie odbudowywać się

${ }^{20}$ L. Cierpiałkowska, M. Ziarko, Psychologia uzależnień - alkoholizm, Warszawa 2010, s. 189-191. 
na nowo. Jednak w przypadku, kiedy następuje rozwód, traci się więzi i relacje. W tej sytuacji należy zastanowić się nad angażowaniem alkoholika w życie rodziny. System rodzinny musi zostać na nowo zorganizowany. Natomiast w innym przypadku, kiedy to alkoholik przestaje spożywać alkohol, relacje budowane są na nowo. Ustabilizowanie życia przez rodzinę polegać powinno na zadbaniu o każdego jej członka. Objęcie pomocą przyczyni się do tego, by mogła ona w pełni prawidłowo funkcjonować 21 .

Natomiast osoby z problemem alkoholowym posiadające wykształcenie wyższe, aktywne zawodowo, zajmujące wysokie stanowiska służbowe, często posiadają przyjaciół oraz potrafią być duszą towarzystwa. Zawsze dbają o swój wizerunek, niejednokrotnie uczęszczają na siłownię lub uprawiają inne sporty. Osoby te piją alkohol „z klasą” i potrafią idealnie ukryć swój problem przed rodziną, współpracownikami, a nawet nie potrafią przyznać się przed samym sobą. Często spożywają alkohol samotnie w barach, czy wieczorami we własnym domu. Dla nich każdy powód jest dobry, by się napić: stresująca praca, sukces zawodowy, odreagowanie napięcia, a nawet fakt, że ciężko pracują, by zapewnić wysoki poziom życia swojej rodzinie. Dlatego też alkohol traktują jako nagrodę za ciężką pracę. Piją regularnie, w dużych ilościach, a codziennie rano regenerują się suplementami, witaminami oraz stosując odpowiednie kosmetyki, by nikt nie dostrzegł problemu. To osoby o dwóch twarzach, w pracy czują się spełnione, aktywne, twórcze, w domu unikają kontaktów z rodziną, trudno im się odnaleźć. Przez lata idealnie ukrywają swój problem. Dopiero w sytuacji, gdy dojdzie do szokującego wydarzenia, jak wypadek drogowy, zwolnienie z pracy, ciężka choroba, rozwód, to osoba ta może uświadomić sobie, że ma problem i wybierze się do poradni uzależnień22.

21 Ibidem.

22 J. Seremak, Alkoholik wysokofunkcjonujacy - kto to taki?, http://www.aptekaniezapominajka.pl/wp-content/uploads/2018/03/alkoholizm.pdf, [dostęp: 24-07-2020]. 
Żaneta Nieckarz - Funkcjonowanie dziecka $w$ rodzinie...

\section{Relacje w rodzinie z problemem alkoholowym}

W sytuacji, gdy w rodzinie pojawia się problem alkoholowy występujący u jednego jej członka, pozostali muszą podjąć decyzję, dokonując wyboru pomiędzy wyraźnym sprzeciwem wobec tego typu zachowania lub jego zaakceptowaniem. Czasem decyzja podejmowana zostaje nieświadomie i rodzina zmienia swoje zachowanie tak, aby było odpowiednie do zaistniałej sytuacji. Prowadzi to do tego, iż alkohol staje się normą postępowania, czynnikiem, od którego zależy funkcjonowanie życia rodzinnego 23 .

Wychowywanie się $\mathrm{w}$ rodzinie z problemem alkoholowym dostarcza trudnych doświadczeń życiowych, silnych odczuć napięć, ciągłego lęku, samotności, dezintegracji. Przykre wydarzenia dnia codziennego, z którym przyszło się zmierzyć i im sprostać, sprzyjają powstawaniu obronnych postaw życiowych ${ }^{24}$. Dlatego też, chcąc przetrwać $\mathrm{w}$ rodzinie z problemem alkoholowym, jej członkowie, by zmniejszyć ciągły stan wzmożonego napięcia nerwowego, przyjmują określone role, które umożliwiają im egzystencję25.

W literaturze możemy poznać kilka propozycji ról pełnionych w rodzinach dysfunkcyjnych. I tak w odniesieniu do dzieci ze wspomnianych rodzin M. Karpel i E Strasus przedstawili propozycję trzech typów ról pełnionych przez potomstwo: „dziecko infantylne”, „kozioł ofiarny”, „dziecko rodzicielskie”. Natomiast D. Field wyróżnił sześć ról pełnionych przez dzieci: „dziecko odpowiedzialne”, „dziecko-samotnik”, „dziecko-Rambo”, „manipulujące dziecko”, „dziecko konformistyczne”, „dziecko niedostosowane”26.

${ }^{23}$ A. Margasiński, Rodzina alkoholowa z uzależnionym w leczeniu, Kraków 2010, s. 61.

${ }^{24}$ M. Parzyszek, Dziecko w rodzinie współczesnej,J. Daszykowska,A. Łuczyński (red.), Dziecko w przestrzeni życia społecznego, Stalowa Wola 2013, s. 87.

25 B. Maciejewska, Dzieci z rodzin z problemem alkoholowym - szansa na rozwój czy droga ku destrukcji?, „,Nowa Szkoła” 2013, nr 8, s. 50.

26 P. Bodzon, Role petnione $w$ systemie rodziny pochodzenia a oczekiwania od matżeństwa i hierarchia wartości u młodych dorosłych, „Kwartalnik Naukowy Fides Et Ratio" 2014, nr 3(19), s. 132, https://www.stowarzyszeniefidesetratio.pl/Presenta tions0/10Bodzon.pdf, [dostęp: 20-07-2020]. 
Z kolei Z. B. Gaś wyróżnia role: „ratownika”, „prowokatora” i „ofiary” przyjmowane przez dzieci wychowujące się w rodzinach z problemem alkoholowym. C. Black wskazuje na zupełnie inne role: „dziecko odpowiedzialne”, „dziecko dopasowujące”, „dziecko łagodzące sytuację"27. $\mathrm{Z}$ uwagi na rozpowszechnienie $\mathrm{w}$ wielu publikacjach i powszechną znajomość ról pełnionych przez dzieci z rodzin z problemem alkoholowym autorka uznała za zasadny wybór jeszcze innej klasyfikacji: „wspólnika”, „,bohatera rodziny”, „,kozła ofiarnego”, „zagubionego dziecka” i „maskotki"28.

W przypadku natomiast współmałżonka ukazana w literaturze rola „wspólnika” polega na ochronie rodziny. Pełni ją zazwyczaj żona ewentualnie mąż, którzy chcą być lojalni wobec współmałżonka nadużywającego alkohol i w ten sposób okazują swoje uczucie. Jednak korzyści wynikające z takiego postępowania są krótkotrwałe. Wspólnik czuje się odpowiedzialny za alkoholika i uważa, że działania przez niego podejmowane pomogą utrzymać równowagę w rodzinie.

W aspekcie emocjonalnym rola wspólnika kształtuje się tym, że staje się przeciążony nadmiarem obowiązków. Niebagatelne znaczenie ma również fakt, że nieustannie musi łagodzić wiele konfliktów, przez co jest niestabilny emocjonalnie. Cierpi wewnętrznie, wzrasta w nim lęk. Obwinia się za każdą sytuację. Odkłada w czasie własne potrzeby lub całkowicie z nich rezygnuje. Poświęcenie się wprowadza w błędne koło i sprawia, że czuje się osobą beznadziejną.

W aspekcie umysłowym i podejmowania decyzji wspólnik na początku staje się osobą samodzielną i wykazuje się odpowiedzialnością. Jednakże ogrom emocji i nieskuteczność wynikająca z wykonywanych działań prowadzi do myślenia, które nie charakteryzuje się analizowaniem. Dlatego też nie jest w stanie realnie ocenić danej sytuacji ${ }^{29}$.

W związku z tym w aspekcie społecznym wspólnik chce chronić alkoholika i całą rodzinę. Unika kontaktów ponieważ czuje wstyd, boi

\footnotetext{
27 M. Ryś, Rodzina z problemem alkoholowym..., op. cit., s. 51.

28 P. Bodzon, Role petnione w systemie..., op. cit.

${ }^{29}$ K. Gąsior, Funkcjonowanie noo-psychologiczne..., op. cit., s. 75.
} 
Żaneta Nieckarz - Funkcjonowanie dziecka $w$ rodzinie...

się odrzucenia i niezrozumienia. Izolowanie się w konsekwencji prowadzi do wyodrębniania rodziny i poczucia samotności. Pod względem fizycznym wspólnik odczuwa nieustający stres, a to wpływa niekorzystnie na jego zdrowie ${ }^{30}$.

Rola „bohatera rodziny”, którą przyjmuje najczęściej najstarsze dziecko, polega na zapewnieniu rodzinie właściwego funkcjonowania. Bohater udowadnia wszystkim wokół, że w rodzinie nic złego się nie dzieje i funkcjonuje ona we właściwy sposób. Bohater jest odpowiedzialny za całą rodzinę, co wykracza ponad jego wiek. Otrzymuje odpowiedzialne zadania, które spełnia. Można więc na nim polegać w każdej sytuacji. Dąży do osiągnięcia przesadnej doskonałości i potrzebuje wykazać się w działaniu. Posiada nadmierne kompetencje. Czuje się odpowiedzialny za rodzinę. Potrzebuje mieć nad kimś kontrolę i dominować nad jego życiem. W ten sposób ukazuje swoje tendencje do roli pełnionych w domu. Bierze odpowiedzialność za członków swojej rodziny. Troszczy się o nich i często wyręcza we wszystkim. Staje się czujny, dostrzega potrzeby innych, zapominając o własnych. Dziecko, które pełni w rodzinie tę rolę, wykazuje trudność z odbieraniem pomocy i troski innych. Nie potrafi się zrelaksować, odpocząć, bawić, jest poważne, brak w nim spontaniczności. W aktywnościach chętnie przyjmuje rolę opiekuna. Bohater przyjmuje dorosłe role, świadczą o tym jego wypowiedzi i emocjonalne podejście ${ }^{31}$. Dlatego też musi podejmować szereg działań, które w pewnym stopniu ustabilizują sytuację rodzinną. Podczas pozytywnego oddziaływania bohater buduje poczucie własnej wartości oraz wywiera pozytywny wpływ na system wartości całej rodziny. Wykazuje duży potencjał intelektualny, by zadbać o siebie i potrzeby swojej rodziny. Nie przywiązuje uwagi do własnego rozwoju. Często jest zły, jednak nie ujawnia tego uczucia, a wręcz go tłumi. Zdarza się, że może pojawić się u niego również obwinianie się. W aspekcie umysłowym i podejmowania decyzji bohaterowi stawiane są nadmierne wymagania, przez co funkcjonuje w błędnym przekonaniu, że musi

\footnotetext{
30 Ibidem, s. 76.

31 M. Goetz, Dzieci w rodzinie dysfunkcyjnej, „Świat Problemów” 2018, nr 4, s. 16.
} 
stawać się jeszcze lepszy. Wpływa to niekorzystnie na jego osobowość. $\mathrm{W}$ aspekcie społecznym bohater jest w centrum uwagi, rówieśnicy go lubią. Wewnętrznie jednak czuje się samotny. Wykazuje chęć pomocy innym. Jednak wyuczony perfekcjonizm sprawia, że ma duże wymagania, jeżeli chodzi o dobór przyjaciół. Zachowuje dystans, który nasila uczucie samotności. W aspekcie fizycznym występuje stres i podatność na uzależnienie od środków uspokajających ${ }^{32}$.

Rola „,kozła ofiarnego” polega na zwracaniu w negatywny sposób na siebie uwagi przez dziecko. Często odnosi ono porażki, które wynikają $\mathrm{z}$ jego bezradności. Posiada słabą samokontrolę, czego konsekwencją są zachowania agresywne i niestosowne. Gdy to w pewnym sensie wołanie o pomoc nie zostanie dostrzeżone, tylko karane, problemy będą narastać ${ }^{33}$. Konsekwencją tego może być sytuacja, w której dziecko szybko opuszcza dom rodzinny, by pozbyć się gniewu. Często podejmuje ono błędne decyzje życiowe, stając się osobą uzależnioną lub należy do grup przestępczych. Chce w ten sposób być dostrzegane.

$\mathrm{W}$ aspekcie emocjonalnym przejawia złość, która wynika z braku okazywania przez rodziców miłości, nienawidzi osoby uzależnionej oraz zazdrości „bohaterowi rodziny”, że jest zauważany. Silne uczucie złości sprawia, że postępuje niewłaściwie wobec innych. W aspekcie umysłowym i podejmowania decyzji posiada tak silne uczucie wzburzenia, gniewu i wrogości, że nie jest w stanie wykazać się zdolnościami. Motywacja występuje sporadycznie. Chce zaimponować rówieśnikom i przyjmuje rolę lidera. Zachowania impulsywne powodują, że zwraca na siebie uwagę. W aspekcie społecznym szuka osób podobnych do siebie, takich, które chcą być zauważane i kochane. „Kozioł ofiarny" nie zna uczucia miłości, nie jest w stanie nikogo nią obdarzyć. W kontakcie z innymi jest płytki. Jest osobą samolubną i dąży do manipulowania i wykorzystywania innych dla własnych korzyści 34 .

\footnotetext{
32 K. Gąsior, Funkcjonowanie noo-psychologiczne..., s. 76.

33 M. Goetz, Dzieci w rodzinie..., op. cit., s. 19.

34 K. Gąsior, Funkcjonowanie noo-psychologiczne..., op. cit., s. 77.
} 
Żaneta Nieckarz - Funkcjonowanie dziecka $w$ rodzinie...

Rola „zagubionego dziecka” zazwyczaj pełniona jest przez trzecie i kolejne dzieci w rodzinie. Starsze rodzeństwo przyjmowało określone role, więc aby odnaleźć się w nowej sytuacji, usuwa się na bok. Jego działania zmierzają do izolacji. Nie odczuwa zainteresowania swoją osobą, więc staje się tak jakby nieobecne i przestaje reagować na sytuację. Zachowanie dziecka jest więc korzystne dla rodziny z problemem alkoholowym, która nie musi poświęcać mu uwagi i sprawować nad nim opieki. W tej sytuacji dziecko zazwyczaj posiada swój własny świat, w którym marzy i rozmyśla ${ }^{35}$. Izoluje się nawet od środowiska, w którym przebywa. W aspekcie społecznym występują u niego negatywne zmiany i nie rozwija swojej osobowości. Nie ma możliwości odczuwania bliskości i intymności. Nie umie dogadać się z innymi, nie wie, jak współpracować i rywalizować. Dziecku nie są stawiane żadne wymagania, nikt niczego od niego nie oczekuje, co przyczynia się do zahamowania rozwoju umysłowego. W aspekcie fizycznym występują zaburzenia psychosomatyczne ${ }^{36}$.

Ostatnia z pełnionych przez dziecko ról to „maskotka”. Dziecko, które pełni tę rolę, tłumi emocje, nie potrafi poradzić sobie ze stresem. Celem jego oddziaływania jest bagatelizowanie napięcia $w$ rodzinie przez żartowanie, wygłupianie się, bycie przesadnie miłym. Wobec takich działań przyjmuje rolę królewskiego błazna, którego zadaniem jest łagodzenie sytuacji. W każdej sytuacji wykazuje optymizm, nawet gdy wymaga ona okazywania innych emocji. Przybiera więc maskę, ukrywa to, co czuje. W rodzinie nikogo nie interesuje, co się z nim dzieje. Dziecko przyzwyczajone jest, że może zwrócić na siebie uwagę wyłącznie przez rozweselanie. Dlatego rzadko ujawnia emocje i mówi o problemach. W sytuacji, gdy się pojawiają, rozmawia o nich z niezwykłą łatwością. Dziecko pełniące tę rolę nie lubi się zwierzać, co powo-

35 A. Gimerska, Analiza treści bajek terapeutycznych dla dzieci z rodzin z problemem alkoholowym, „Biblioterapeuta: Biuletyn Informacyjny Polskiego Towarzystwa Biblioterapeutycznego" 2014, nr 4, s. 21.

${ }^{36}$ K. Gąsior, Funkcjonowanie noo-psychologiczne..., op. cit., s. 78. 
duje trudności w nawiązywaniu bliższych relacji z rówieśnikami. Potrafi żartować z tego, co sprawia mu trudność i ból ${ }^{37}$.

Rola ta przyjmowana jest przez najmłodsze dziecko. Nie wie ono zazwyczaj, co się dzieje, ponieważ otrzymuje błędne sygnały. „Maskotka” zauważana jest wtedy, gdy pełni swoją rolę. Czuje się samotna, nawet gdy uwaga skierowana jest na jej osobę. W aspekcie społecznym posiada kontrolę nad sytuacjami, manipuluje nimi, osiągając zamierzone cele. Potrafi skoncentrować uwagę na samym sobie. Umie odnaleźć się społecznie, jednak pełniona rola sprawia, że ogranicza się do błaznowania. Często wykazuje nieadekwatne reakcje na zdarzenia wobec relacji z najbliższymi. W aspekcie umysłowym i podejmowania decyzji maskotka posiada zahamowany rozwój swojego intelektualnego potencjału. Przejawia trudności w radzeniu sobie ze stresem, a wobec trudnych sytuacji pozostaje bezradna ${ }^{38}$. Role, które przyjmują dzieci w rodzinach z problem alkoholowym, można określić jako przyjmowanie fałszywej osobowości. Stanowią one reakcje dążące do stawiania czoła zaistniałej sytuacji, to obrona istniejącej rzeczywistości. Pozwala to dziecku doraźnie przetrwać chorobę członka rodziny, ale też daje możliwości ukrycia tego faktu przed innymi ludźmi, którzy mogliby dostrzec problem i przyjść z pomocą. Ważnym elementem jest, by pomóc dzieciom w pozbyciu się fałszywej osobowości. Należy sprawić, aby zaakceptowały siebie bez roli, jaką pełnią w rodzinie dysfunkcyjnej ${ }^{39}$.

\section{Pomoc dzieciom przyjmującym określone role w rodzinie z problemem alkoholowym}

Niezwykle istotne jest, by jak najszybciej dostrzec dzieci, które przyjmują określone role, po to, aby pomóc im wyjść z błędnego koła. Role te bowiem stanowią ich zdaniem rozwiązanie w tej trudnej sytua-

37 M. Goetz, Dzieci w rodzinie..., op. cit., s. 17.

38 K. Gąsior, Funkcjonowanie noo-psychologiczne..., op. cit., s. 78-79.

39 B. E. Robinson, J. L. Rhoden, Pomoc psychologiczna dla dzieci alkoholików, Państwowa Agencja Rozwiązywania Problemów Alkoholowych, Warszawa 2003, s. 63-64. 
Żaneta Nieckarz - Funkcjonowanie dziecka $w$ rodzinie...

cji. Kształtują się one w różny sposób i wymagają różnego podejścia. Pomoc „,bohaterowi rodziny” polegać powinna na stworzeniu warunków, aby mógł być dzieckiem. Z racji tego, że wykazuje przejawy bycia zbyt dojrzałym. Zasadne staje się umożliwienie mu wyrażania własnych uczuć i potrzeb. Dzieci powinny być obdarzone taką samą uwagą, jak inne, mimo tego, że dobrze sobie radzą. Dla bohatera konieczne jest wsparcie, by mógł dostrzec potrzebę zabawy i zrównoważyć ją z obowiązkami. Pożądane jest również stwarzanie różnych sytuacji, w których rola się zamienia i ktoś inny robi coś dla niego, wykazując troskę. Powinien mieć stawiane oczekiwania, jednak adekwatne do wieku. Należy uświadamiać bohatera, aby znalazł czas również dla siebie, na zabawę, odpoczynek, jak również realizowanie własnego hobby. Dziecko powinno dojść do wniosku, że poświęcanie czasu sobie nie powoduje tracenia go. Powinno mieć możliwość realizowania siebie, więc należy dążyć do stworzenia mu okazji, aby mógł poszukiwać i rozwijać własne zainteresowania. Należy dowartościowywać je i pokazywać, że jest się zadowolonym z jego sukcesów. Unikać należy uwag, że rodzice są z ciebie dumni, ponieważ potęguje to wgłębianie się $\mathrm{w}$ pełnioną przez niego rolę. Dziecko powinno umieć akceptować i przyjmować do wiadomości własne porażki. Wpajać należy, że jest to coś zupełnie naturalnego i każdy musi doświadczyć wszystkiego, by uczyć się na własnych błędach. Należy uświadamiać, że nikt nie jest doskonały i nie należy dążyć do perfekcjonizmu za wszelką cenę. Rozmowa o potrzebach, uczuciach, emocjach jest równie ważna. Dziecko będzie miało świadomość, że okazywane jest mu zainteresowanie. Należy zachęcać je do spontanicznych działań ${ }^{40}$.

Z kolei pomoc „kozłowi ofiarnemu” powinna polegać na odpowiednim nastawieniu do dziecka. Jeżeli go nie lubimy ze względu na jego zachowanie, należy uzmysłowić sobie, że wynika ono z wołania o pomoc. Przede wszystkim należy dostrzec potencjał intelektualny i pracować nad nim. Uświadomić dziecku, że się w nie wierzy i spodziewa od niego czegoś dobrego. Należy wykazać się cierpliwością, zachowy-

40 M. Goetz, Dzieci w rodzinie..., op. cit., s. 17. 
wać spokój, kiedy źle postępuje. Nie karać, tylko przekazać konkretną informację zwrotną. Oceniać zachowanie, a nie jego samego. Pokazywać, że postępowanie jest niewłaściwe. Dziecko powinno być uczone wyrażania własnych emocji bez stosowania przemocy fizycznej. Istotne jest, aby doceniać nawet małe postępy, rozmawiać i przez rozmowę dotrzeć do prawdziwej jego osobowości. Dziecko nie będzie czuło dystansu i w końcu pozbędzie się maski, za którą ukrywa swoje uczucia ${ }^{41}$.

Pomoc „zagubionemu dziecku” powinna polegać na wykazywaniu drobnych gestów zainteresowania. Należy nie dać nabrać się złudzeniu, że dziecko nas nie potrzebuje. Okazać troskę i uwagę, stwarzać sytuacje, podczas których może ono pokazać, że istnieje i się może zaprezentować w jakiś sposób. Dziecko powinno tworzyć pomysły i rozwiązania problemów, wobec tego istotne jest zachęcanie do podejmowania takich działań. Pozwolić mu wyrazić to, co czuje w innej formie, np. przez twórczość plastyczną. Omawiając jego wytwory, poznać można jego emocje i uczucia. Należy podnosić samoocenę przez chwalenie działań. Krytykę wyrażać w sposób konstruktywny. Starać się integrować dziecko z innymi osobami. Podbudować jego samoocenę przez odkrywanie wraz z nim jego mocnych stron, zdolności i szans rozwojowych ${ }^{42}$.

Z kolei pomoc dziecku, które przyjmuje rolę „maskotki”, powinna polegać na okazywaniu zainteresowania i przede wszystkim zrozumienia, które pozwoli mu z biegiem czasu się otworzyć. Należy uświadomić mu, że akceptuje się go jako osobę w pełni i nie musi zwracać na siebie uwagi przez żartowanie i błaznowanie. Dążyć do tego, by ukazywało prawdziwego siebie. Dać mu możliwość do wyrażania siebie w różnych formach, jednak nie należy narzucać presji. Należy raczej być empatycznym i umiejętnie wczuć się w sytuację. Pokazać dziecku, jak może reagować w różnych sytuacjach. Nauczyć, że wyrażanie emocji i słabości nie jest niczym złym. Można użyć do tego zabawek, czy też history-

\footnotetext{
41 Ibidem, s. 19.

42 Ibidem, s. 18.
} 
Żaneta Nieckarz - Funkcjonowanie dziecka $w$ rodzinie...

jek, które w naturalnych warunkach będą wspierały w wyjawianiu emocji ${ }^{43}$.

Pełnienie przez dzieci ról może stać się integralną częścią ich osobowości. Brak odpowiedniej pomocy już w dzieciństwie może być zagrożeniem dla ich życia $\mathrm{w}$ dorosłości, gdyż przez lata czerpały z tego faktu satysfakcję, a w dorosłym życiu przestają pełnić swą funkcję. Ważne jest, by wzorce zachowań nie zostały utrwalone, dlatego powinny otrzymać pomoc jak najwcześniej. W sytuacji, gdy pomoc nie zostanie udzielona, role mogą być przyczyną porażki życiowej, z powodu której dorosłe dzieci alkoholików szukają pomocy, ucieczki lub pociechy w alkoholu, narkotykach, seksie, pracy, jedzeniu i różnych innych kompulsywnych sposobach postępowania i zachowania ${ }^{44}$.

Rodzina, pokonując wiele problemów towarzyszących nadużywaniu alkoholu przez jednego rodzica lub nawet obojga, potrzebuje pomocy i wsparcia instytucjonalnego ${ }^{45}$. Mogą go udzielić: Centrum Pomocy Dziecku i Rodzinie, poradnia psychologiczno-pedagogiczna, ośrodek pomocy społecznej, placówka wsparcia dziennego, ośrodek terapii i leczenia uzależnień. Są to miejsca, w których rodziny mogą szukać stosownej pomocy ${ }^{46}$.

Niezwykle ważne jest przy tym to, żeby pomoc udzielana takim dzieciom przebiegała wieloaspektowo. Do pracy z dzieckiem należy odpowiednio przygotować wychowawców, pedagogów, psychologów oraz nauczycieli, by potrafili dostrzec problem, zdobyć zaufanie dziecka i udzielić właściwej pomocy. Istotna jest również nieinstytucjonalna pomoc: wsparcie rówieśników, sąsiadów i dalszej rodziny ${ }^{47}$.

43 B. E. Robinson, J. L. Rhoden, Pomoc psychologiczna dla dzieci.., op. cit., s. 70-71.

44 Ibidem, s. 72-73.

45 A. Witkowska-Paleń, Placówki wsparcia dziennego w systemie pomocy rodzinie dysfunkcyjnej, „Pedagogia Ojcostwa” 2012, nr 5, http://www.pedkat.pl/images/czaso pisma/po5/P0513.pdf, [dostęp: 7-07-2020].

${ }^{46}$ S. Badora, B. Czeredrecka, Rodzina i formy..., op. cit., s. 128-129.

47 B. Bocian-Waszkiewicz, Dziecko niewidzialne - dziecko „we mgle” - charakterystyka dziecka krzywdzonego i wieloaspektowa pomoc, „Student Niepełnosprawny: szkice i rozprawy" 2018, nr 18(11), s. 159. 


\section{Podsumowanie}

W artykule ukazano nadużywanie alkoholu jako czynnik wywołujący dysfunkcjonalność rodziny. Przedstawiony został zaburzony w wyniku tego system funkcjonowania całej rodziny. Ukazane zagadnienie zostało omówione według specyfiki dysfunkcjonalności systemu rodzinnego. Omówiono sytuację dziecka, bazując na pełnionych przez niego rolach. Podjęto próbę ukazania działań pozwalających porzucić deprecjonujące role i zadania, wskazano możliwości właściwego oddziaływania na rozwój dziecka. Zwrócono uwagę na fakt, że dysfunkcjonalność wynikająca $\mathrm{z}$ zaistniałej sytuacji problemowej burzy właściwe relacje i ma negatywny wpływ na funkcjonowanie systemu rodzinnego. Zaprezentowana problematyka została przedstawiona ze szczególnym uwzględnieniem rodziny jako całości. Na podstawie tych informacji można dostrzec, że dziecko trwając $w$ tym systemie i pełniąc określone role, każdego dnia zaburza swój potencjał intelektualny i rozwój. Wybrana literatura przedstawia w sposób przekonujący, że problem alkoholowy ma wpływ na całą rodzinę, a konsekwencje stają się szczególnie bolesne i stresujące. Funkcjonowanie dziecka w takich warunkach ma ogromny wpływ na jego życie codzienne i przyszłość.

\section{Bibliografia:}

Badora S., Czeredrecka B., Marzec D., Rodzina i formy jej wspomagania, Oficyna Wyd. Impuls, Kraków 2001.

Bocian-Waszkiewicz B., Dziecko niewidzialne - dziecko „we mgle” - charakterystyka dziecka krzywdzonego i wieloaspektowa pomoc, „Student Niepełnosprawny: szkice i rozprawy" 2018, nr 18 (11).

Cierpiałkowska L., Ziarko M., Psychologia uzależnień - alkoholizm, Wyd. Akademickie i Profesjonalne Spółka z o.o., Warszawa 2010.

Daszykowska J., Łuczyński A. (red.), Dziecko w przestrzeni życia społecznego, Wydział Zamiejscowy Nauk o Społeczeństwie KUL w Stalowej Woli, Stalowa Wola 2013. 
Żaneta Nieckarz - Funkcjonowanie dziecka $w$ rodzinie...

Gąsior K., Funkcjonowanie noo-psychologiczne i problemy psychiczne dorosłych dzieci alkoholików, Wyd. Delfin SA, Warszawa 2012.

Gąsior K., Jak uwolnić się od destrukcyjnych przekazów rodzinnych?, „,Świat Problemów" 2011, nr 5.

Gimerska A., Analiza treści bajek terapeutycznych dla dzieci z rodzin z problemem alkoholowym, „Biblioterapeuta: Biuletyn Informacyjny Polskiego Towarzystwa Biblioterapeutycznego" 2014, nr 4.

Goetz M., Dzieci w rodzinie dysfunkcjonalnej, „Świat Problemów” 2018, nr 4.

Grzegorzewska I., Dorastanie $w$ rodzinach z problemem alkoholowym, Wyd. Naukowe SCHOLAR, Warszawa 2011.

Kozłowska A., Znaczenie relacji rodzinnych dla pozytywnego rozwoju dziecka. Diagnoza i terapia, Centrum Metodyczne Pomocy Psychologiczno-Pedagogicznej, Warszawa 2000.

Krzesińska-Żach B., Pedagogika rodziny. Przewodnik do ćwiczeń, Wyd. Uniwersytetu Trans Humana, Białystok 2007.

Maciejewska B., Dzieci z rodzin z problemem alkoholowym - szansa na rozwój czy droga ku destrukcji?, „Nowa Szkoła” 2013, nr 8.

Margasiński A., Rodzina alkoholowa w uzależnionym w leczeniu, Wyd. Oficyna Wydawnicza „Impuls”, Kraków 2010.

Marzec H. (red.), Z rodzina i dla rodziny $w$ dobie globalizacji, T. II, Wyd. Piotrkowskie przy Filii Uniwersytetu Humanistyczno-Przyrodniczego Jana Kochanowskiego w Piotrkowie Trybunalskim, Piotrków Trybunalski 2011.

Pospiszyl I., Patologie społeczne, Wyd. Naukowe PWN, Warszawa 2009.

Robinson E. B., Rhoden L. J., Pomoc psychologiczna dla dzieci alkoholików, Wyd. Państwowa Agencja Rozwiązywania Problemów Alkoholowych, Warszawa 2003.

Różycka E. (red.), Encyklopedia pedagogiczna XXI wieku, T. I, Wyd. Akademickie „Żak”, Warszawa 2003.

Ryś M., Rodzina z problemem alkoholowym. Metody badań relacji interpersonalnych $w$ dysfunkcyjnych systemach rodzinnych, Drukarnia Dimograf, Warszawa 2014.

Szczukiewicz P., Sposoby adaptacji dzieci w rodzinie alkoholowej, „Świat Problemów" 2016, nr 10, s. 33-36.

Urban B., Stanik M. J., (red.), Resocjalizacja: teoria i praktyka pedagogiczna, T. 2, Wyd. Naukowe PWN, Warszawa 2008.

Wosik-Kawala D. (red.), Rodzinne i instytucjonalne środowisko opiekuńczowychowawcze, Wyd. Uniwersytetu Marii Curie-Skłodowskiej, Lublin 2011. 


\section{Netografia:}

Bodzon P., Role pełnione w systemie rodziny pochodzenia a oczekiwania od matżeństwa i hierarchia wartości u młodych dorosłych, „Kwartalnik Naukowy Fides Et Ratio", 2014, nr 3(19), https://www.stowarzyszeniefidesetra tio.pl/Presentations0/10Bodzon.pdf, [dostęp: 20-07-2020].

Seremak J. Alkoholik wysokofunkcjonujacy - kto to taki?, http://www.aptekaniezapominajka.pl/wp-content/uploads/2018/03/alkoholizm.pdf, [dostęp: 24-07-2020].

Witkowska-Paleń A., Placówki wsparcia dziennego w systemie pomocy rodzinie dysfunkcyjnej, „Pedagogia Ojcostwa” 2012, nr 5, http://www.pedkat.pl/ images/czasopisma/po5/P0513.pdf, [dostęp: 7-07-2020]. 